\title{
Structure-reinforced privilege: Educational inequality in the Singaporean primary school choice system
}

\author{
Mira Debs and Hoi Shan Cheung
}

\begin{abstract}
Prior research on school choice as a global educational policy has emphasized how parents use their privileges to gain advantages. In contrast, we use the theoretical framework of structurereinforced privilege to highlight how parental advantage can be compounded by complex choice structures, both the number of choices and the complicated selection criteria. We focus on a case study of Singapore's primary school registration process which has not been previously examined in the academic literature. Using a discourse analysis of newspaper coverage and a Singaporean website for parents, we demonstrate that the primary enrollment system creates confusion among parents, and ultimately allows privileged parents to gain an admissions advantage in perceived elite schools. Numerous admission preferences, while initially intended to strengthen family-school ties, rewards those with resources, furthering the perception and reality of economic inequality. We close with recommendations to simplify school choice systems giving priority to families with limited resources.
\end{abstract}

Key words: Parents, school choice, parent involvement, education policy, segregation, inequality, Singapore 


\section{Introduction}

In the last twenty years, school choice has been expanding as a global educational policy (Adamson, Åstrand and Darling-Hammond 2016, Forsey, Davis and Walford 2008). Choosing schools has been promoted as the solution to increasing student achievement, offering educational individualization, introducing competition into the public sector and providing greater access for poor students to quality schools (Chubb and Moe 2011, Dronkers and Robert 2008, Salman 2010, Wu, 2020). Yet this shift from education as a right to a consumer good has shifted the relationship between parents, schools and states (Proctor et al. 2020). In aggregate, studies of countries as varied as Australia, Canada, Chile, China, Korea and Sweden suggest that the impact of school choice has been increasing educational inequality and segregation (Adamson, Åstrand and Darling-Hammond 2016, Byun, Kim and Park 2012, Lubienski and Yoon 2017, Rowe and Lubienski 2017, Wu 2012).

To explain why school choice leads to inequality, researchers have focused on parents competing to have their children admitted to the same small set of schools, particularly in countries like Germany and Hong Kong where government-funded schools are the central educational model (Dumont, Klinge and Maaz 2019, Zhou, Wong and Li 2015). Parents' economic, cultural and social capital contribute to successfully navigating complex choice systems such as in the UK, US and Singapore (Ball and Vincent 1998, Posey-Maddox 2014, Tan 2017). But just as school choice has transferred risk and responsibility to parents (Shuffelton 2020), the research shift to parents has led to what Christiansen terms "the widespread indictment of parents as obstacles to education reform" $(2015,563)$. This critique of parents, while important, risks minimizing the important way choice systems are designed to enable parents disproportionate access, specifically the number of choices and the way that school 
enrollments are structured. Some research has examined this interaction as policymakers have responded to the transformation of parents as "customers" (Breidenstein, Krüger and Roch 2020) in some instances by increasing elite schools such as in the Netherlands, although the research focus thus far has been on the school choices rather than the design of the choice system (Merry and Boaterman, 2020).

A case study of one global educational model, Singapore, helps illustrate how the interaction between parents and school choice systems allows for what we term structurereinforced privilege, where the design of the choice structures themselves reinforces the existing privileges of some parents. Though Singapore is a small city-state, its education system holds disproportionate sway internationally due to its stellar PISA results (Darling-Hammond 2015, P. T. Ng 2017). In part due to a high cost of living and land scarcity, the competitive path to economic success in Singapore begins with getting into a "good" primary school (Ong and Cheung 2016). In contrast to many countries where children go to the nearest school, Singapore's intense competition for school seats begins with primary school enrollment at age seven that combines a large number of choices (185 government schools and government-aided schools) and a complicated six-tier enrollment preference system (giving preference to those with prior affiliations with the school through a sibling, parents teaching at the school, alumni affiliation, religious or clan affiliation and parent volunteer status). Previous studies of Singapore have emphasized how parents drive educational inequality, focusing on purchasing property near "elite" schools, using private tutoring (a \$1.7 billion industry in Singapore) (Chin and Foong

\footnotetext{
${ }^{1}$ The term "elite schools" is controversial in Singapore, and politicians often substitute "popular" or "sought-after" schools (Ang 2018). We observed parents online using "branded," "popular" or "hot" schools versus "generic" or "neighborhood" schools, rather than acknowledge the elite or non-elite statuses. In our project, we highlight both the material differences between schools and the parental perceptions that reinforce these differences, We use 'elite' intentionally to describe this status-hierarchy.
} 
2006, Tan 2017, Teo 2019), as well as a culture of individual meritocracy internalized by parents of all social classes (Chiong and Dimmock, 2020). To our knowledge, however, the impact of Singapore's primary school choice process on educational inequality has not been documented in an academic study.

Educational competitiveness results in a cultural phenomenon that Singaporeans call kiasu, a Hokkien Chinese term that roughly translates to "fear of losing out." "Being kiasu" is used both critically and self-referentially around the island nation (Barr and Skrbiš 2008). Thus, the term kiasu parent is simultaneously a badge of honor reflecting Singaporean parents' sacrifices to secure their children's futures, the name of Singapore's most popular online parenting forum, and an indictment of problematic Singaporean parenting practices.

The consequences of this competition are significant levels of educational stratification: a 2018 OECD study found that $46 \%$ of socioeconomically disadvantaged Singaporean students attended schools with concentrated levels of student poverty (OECD 2018: 28). ${ }^{2}$ Echoing recent international education research, Singaporean policy makers have pointed blame at parents, suggesting that changing the system is not a matter of making the schools better, but "redefin[ing] what a good school is in the minds of Singaporeans," (P. T. Ng 2017). Similarly, in 2013, then Education Minister Heng Swee Keat gave a speech arguing that "if parents' mindsets don't change, whatever changes we make [to improve schools] will not have any impact" (Heng and Ong 2013). In these framings, parents are too kiasu, instead of the process being too competitive. Examining how Singaporean parents interact with the primary school choice

\footnotetext{
2 Defined as students whose economic, social and cultural status (ESCS) on the PISA index are among the bottom $25 \%$ within their country, and schools in the bottom $25 \%$ based on the average ESCS index among students in a school.
} 
process through their public discourse illuminates how these structures give preference and advantage to those with resources.

This study adds to the comparative international education research on school choice and parent involvement by examining the dynamic interaction between parents and choice structures that facilitate and even exacerbate their using the system to their advantage. We see structurereinforced privilege moving beyond blaming parents for hoarding resources to examining the dynamic interaction between structures (the number of schools available, the structure of how families enroll,) combined with how parents navigate those structures (the information parents access and the resources they have to operate in the system.) We pose the questions, how does the structure of the Singaporean primary school enrollment system interact with parents, and whom does it advantage? How might it be changed?

A discourse analysis of 10 years of local press coverage and five years (2015-2020) of enrollment pages of the Singaporean parent-run website Kiasuparents illustrates how parents navigate this complicated enrollment process. We argue that 1) the design of Singapore's primary school registration system, with many choices and a tiered preference system creates confusion allowing for structure-reinforced privilege, enabling privileged parents to boost their children's chance of admissions into "perceived" elite schools. 2) The phased balloting process and the looming scarcity of seats in desirable schools hardens the perception of significant differences between schools. This perception in turn becomes self-fulfilling, leading families to shun undesirable schools, contributing to socioeconomic segregation and ultimately, greater social inequality. 3) We conclude with recommendations for how choice systems might be simplified giving preference to families with the most limited resources. 


\section{Theoretical frame}

In examining the mechanisms by which school choice in countries around the globe leads to segregation (Adamson, Åstrand and Darling-Hammond 2016, Byun, Kim and Park 2012, Lubienski and Yoon 2017), research has turned to the role of parents who are the primary choosers for their child's education. Sociology of education researchers have long documented how child-rearing practices can further educational inequality. Building off Pierre Bourdieu (1986), these resources can be divided up into economic, cultural capital and social capital. Economic resources enable parents to enroll their children in private schools, fundraise for their child's school, and pay for private lessons which give their children both academic and extracurricular advantages (Park et al. 2016). Student cultural capital, in the form of knowledge and behaviors, has been shown to influence teachers' perception of academic abilities, influencing subsequent academic success (Bourdieu 1996). While Bourdieu observed the French education system, scholars have argued for capital's applicability to Asian educational contexts where the emphasis on parental responsibility and work ethic may carry even more weight than in European and North American systems (Saha 2003, Yamamoto and Brinton 2010).

In the school choice process, parents' access to capital matters, even as public education systems take pains to emphasize that no one is privileged in the process. In Asian case studies, parental economic, cultural and social capital are influential in accessing desirable schools. Parents in Korea, China and Singapore use economic capital to move into selective school catchment areas and pay for tutoring (Byun, Kim and Park 2012, Chin and Foong 2006, Park et al. 2016, Tan 2017). Chinese parents sometimes pay a "choice fee" equivalent to thousands of US dollars for school entry, or develop their children's cultural capital through becoming a “special talent student" (Wu 2012). 
This capital becomes especially important in the context of a complex school choice process. In recent years, cities around the globe have expanded options beyond the local school resulting in upwards of 100 choices, even for elementary school (Adamson, Åstrand and Darling-Hammond 2016). Ironically, adding choices actually reduces consumer satisfaction (Iyengar and Lepper 2000), and even though wealthier parents have advantages in navigating choices, complex lottery processes can make them feel disempowered as well (Makris 2018). Meanwhile, families with fewer resources experience only the "trappings of choice," of being chosen rather than choosing (Rosenbloom 2010).

Thus it is important to study the complexity of the choice system in interaction with parental privilege. In contrast to emphasizing how parents monopolize resources, we highlight how systems can privilege parents with economic, social and cultural capital, what we call structure-reinforced privilege. This privilege emerges when choice systems have 1) lots of choices 2) an array of selection mechanisms that give weight to parent, student or residential criteria. In reaction to this choice confusion, parents participate in information sharing, either in informal social settings or online, but ultimately, only some parents have the resources to use this added information to gain privileged access in the choice system. Hence, analyzing parent discourse on the extent of information sharing about school choices brings to light the confusion parents experience as they navigate the complex school choice system in Singapore; revealing how these choice structures may reinforce existing parental privilege.

\section{The Singaporean education context}

Singapore's competitive academic system based on school choices hinges on the centrality of education to Singapore's economic strategy, using highly educated human capital to compensate for limited natural resources (P. T. Ng 2017). Today, Singapore's population of 5.7 
million includes 3.5 million Singaporean citizens, and Chinese Singaporeans make up threequarters of the citizen-population, followed by Malay (13.4\%), and Indians (9\%) (Singapore Department of Statistics 2019). ${ }^{3}$

After independence from Britain and subsequent separation from Malaysia in 1965, the island was ethnically divided, with a patchwork of schools including elite English-medium colonial schools and mother-tongue schools set up by the Chinese and Tamil immigrants and the indigenous Malay community. In the decades that followed, the government incorporated many of these pre-colonial schools as government-aided schools, part of a new comprehensive English medium-education system as they strove to create a unified Singaporean public, while preserving mother tongue languages, reducing dropouts and developing the next generation of leaders (Deng and Gopinathan 2016).

Focusing on the struggling students and future leaders led the Ministry of Education (MOE) to launch academic tracking in 1980 starting from primary 4, creating pressure to get into a high track in order to place into a good secondary school. This intensified the pressure on families for choosing a good primary school that would give their children a head start. Subsequent reforms in the 1980s further rewarded high achieving students by creating additional elite programs, directing government funding towards the Special Assistance Plan (SAP) Chinese immersion schools serving the top $10 \%$ of secondary school students, as well as the Gifted Education Program (GEP) for the top 1\% of primary school students. ${ }^{4}$

\footnotetext{
${ }^{3}$ An additional 500,000 people are permanent residents and 1.7 million are guest workers.

${ }^{4}$ Malay and Tamil immersion schools, set up by community groups, were not part of the SAP school initiative and moved from 7\% of enrollment in 1959 to completely closing in the 1980s (Goh and Gopinathan 2008).
} 
As of 2020, Singapore has 185 government aided or fully government funded primary schools. ${ }^{5}$ While all teachers are allocated to schools by the MOE, government aided schools are privately owned, receive additional funds from fundraising and have some added autonomy. Alongside funding, several other distinctions contribute to a perceived hierarchy of schools. Ong and Cheung outline a three-tiered hierarchy of schools- Tier 1 "elite" schools, Tier 2 "non-elite" and Tier 3 neighborhood schools (2016). In Table 1 below, we update Ong and Cheung's schema with 2020 school data. As Table 1 shows, the 17 Tier 1 elite schools often house special programs like GEP or SAP, serve as feeders to popular secondary schools and were established during the British era or by Chinese clan associations resulting in significant alumni and community donations. The 32 Tier 2 schools are also partially funded by donations, some are SAP schools, and all are popular choices among Singaporean parents. The 146 Tier 3 neighborhood schools form the majority of Singapore's primary schools and enroll the majority of students living in nearby government housing where roughly $80 \%$ of Singaporeans reside. Importantly, there is no official data on primary school performance to distinguish between schools (Teng and Yang 2016). An earlier test-based ranking system was in place from 1991 until 2012 when MOE stopped sharing the top performing students at each school taking the year 6 Primary School Leaving Examination (PSLE) (Chew 2012). However, parents quickly developed a workaround, sharing each school's top-scoring PSLE students on Kiasuparents forum.

\footnotetext{
${ }^{5}$ Regardless of the funding structure, primary school tuition is fully-subsidized by the government, but parents pay for school transportation and a small monthly fee for school materials. This analysis excludes international schools, and the six Islamic Madrasahs, which are not regulated by the MOE.
} 
Table 1: Categories of Singaporean primary schools, updated from Ong and Cheung (2016) $(\mathrm{N}=185)$

\begin{tabular}{|c|c|c|}
\hline School Tier & $\begin{array}{l}\text { Number } \\
\text { of schools }\end{array}$ & Characteristics \\
\hline Tier 1 "Elite" schools & 17 & $\begin{array}{l}\text { Either fully funded (government schools) or } \\
\text { partially funded (government-aided schools) with } \\
\text { extensive private donations. } \\
\text { Specialized programs (e.g. SAP, GEP). } \\
\text { Located in wealthier neighborhoods. } \\
\text { Direct affiliation with elite secondary school or } \\
\text { mixed-schools w/primary and secondary schools } \\
\text { (12 schools). } \\
\text { Lottery to enroll because of excess demand. }\end{array}$ \\
\hline $\begin{array}{l}\text { Tier } 2 \text { "non-elite" } \\
\text { government-aided schools }\end{array}$ & 32 & $\begin{array}{l}\text { Partially-funded by the government and some } \\
\text { private donations. } \\
\text { Some specialized programs - e.g., SAP schools. } \\
\text { Located in less wealthy neighborhoods. } \\
\text { Lottery to enroll for most schools. }\end{array}$ \\
\hline $\begin{array}{l}\text { Tier } 3 \text { "non-elite" } \\
\text { neighborhood schools }\end{array}$ & 136 & $\begin{array}{l}\text { Government funded, limited external fundraising. } \\
\text { Few special programs. } \\
\text { Greater percentage of students from government } \\
\text { HDB flats and rental flats. } \\
\text { Few secondary school affiliations. } \\
\text { Most students enroll through neighborhood } \\
\text { preference. }\end{array}$ \\
\hline
\end{tabular}

In Singapore, recent research has demonstrated the stratifying consequences of parental interventions and the concentration of wealthy students in elite schools (OECD 2018, Ong and Cheung 2016, Teo 2019). Economists have documented that proximity to Tier 1 and Tier 2 schools contributes to an increase in housing prices around the island (Chin and Foong 2006), benefiting those who can afford to buy a property near an elite school. This educational stratification has reached the attention of Singaporean leadership. In a 2018 parliamentary debate, Prime Minister Lee Hsien Loong addressed concerns that elite schools risked becoming "self-perpetuating closed circles," a separation causing an elite group "to only look after its own 
interests, and fail in their duty to lead and to care for the rest of society" (Tham 2018). These remarks warn that Singapore's educational divisions risk expanding into broader social schisms. Yet missing thus far is an examination of how early this division begins with the primary enrollment process, which the present study seeks to address.

\section{Case and Methods}

This study utilizes discourse analysis of publicly available data via newspaper articles from 2010-2020 and a popular online parenting forum, Kiasuparents (2015-2020). While discourse analysis cannot allow us to claim that perspectives are representative of a broader Singaporean public, it allows us to examine debates among stakeholders in their social context over a relatively long time (Johnstone 2018). Comparative education research has employed discourse analysis to examine how public policies are simultaneously reflected and created (Saraisky 2015). For example, Waldow, Takayama and Sung (2014) analyzed media discourse surrounding several countries' performance in PISA to demonstrate how a country develops a reputation as an international educational model. Such media analyses provide one of the key pathways through which education policies are communicated and discussed in the public arena.

The present study adopted the same approach, by analyzing media discourse of 170 articles on primary school admissions in the last 10 years from four Singaporean Englishlanguage news platforms - The Straits Times, The New Paper, Today and the Singapore Government News. ${ }^{6}$ All of the print media in Singapore have close ties with the government, with many media leaders coming from positions in the civil service (George 2012). Journalists are expected to promote nation-building, multi-ethnic harmony and social stability while

\footnotetext{
${ }^{6}$ We used the global news search engine Factiva. Search phrases include "phase", "MOE", "2A or $2 \mathrm{~A}(1)$ or $2 \mathrm{~A}(2)$ ", "2B", " $2 \mathrm{C}$ ", "primary one" and "elite or "volunteer" or "grassroot" or "ballot" or "school choice".
} 
respecting what is colloquially referred to as "OB markers," topics considered out-of-bound in public discourse (ibid.) Despite these close ties, news articles on school selections still present perspectives that are sometimes critical of government policies.

Complementing the data obtained from news outlets, we also collected data from the parent-run website Kiasuparents, a "ground-up" forum started in 2007 by three Singaporean parents to share information about education from preschool through university. Research has shown that online forums where members discuss sensitive issues authentically without the usual social constraints can be a useful source of data (Holtz, Kronberger and Wagner 2012). Following American researchers who have used online parent networks to study the inequalities of school choice and the social construction of school quality (Freidus 2019), we rely on Kiasuparents to capture a large volume of data representing public discourse. With a total of 1.8 million posts, nearly 179,000 registered members and up to 10,000 daily users, Kiasuparents was recognized as one of the top 10 Singaporean websites in 2010 (Heng 2013). In contrast to newspapers that hew closely to official government discourse, Kiasuparents is anonymous, albeit with extensive etiquette and moderation guidelines, functioning as a central public forum for discussing educational policies.

Though there is limited data on Kiasuparents users, active posters are likely titled towards highly educated English speaking parents, as reflected in the high usage of standard English rather than colloquial Singaporean English. Even so, the forum provides a useful public litmus of the perspectives of relatively privileged parents as they consider primary school choice.

Our analysis focused on the Primary Schools Selection and Registration section of Kiasuparents which included 81 threads from 2008 through 2020 ranging from 0 to 5068 replies. We focused on five relevant and highly commented threads and narrowed our focus to comments 
from 2015-2020, coding a total of 2737 comments. The threads were 1) Choosing and evaluating primary schools (960 comments from 2015-20) 2) All about parent volunteers (580 comments) 3) Are Our Children's Future Predicated on Good Primary Schools? (92 comments) 4) Opinions of the Primary School Registration System (998 comments) and 5) Are All Primary Schools The Same? (107 comments).

We then used inductive coding with both sets of data to identify key themes. Author 1 coded the Kiasuparents data using the coding software NVivo while Author 2 coded the newspaper data. The results were compared weekly through analytical memos, relying on codes with high levels of frequency and finding a triangulation of the data based on the two sources. Key themes included balloting strategy, the fairness of the priority schemes and the government's responses to public perceptions. Although the interpretation of the data would naturally be influenced by the coders' backgrounds, the composition of this research team ensured that the data were analyzed and interpreted from more than one cultural lense and academic perspective. Author 1 is an American sociologist who studies school choice and parent involvement. Author 2 is a Singaporean developmental psychologist and has both researched the psychological impact of school streaming on Singaporean students, and has navigated the Singaporean primary school enrollment process as a parent. Having the insights of both a Singaporean citizen and a foreigner enabled us to leverage both insider knowledge and outsider analysis, drawing comparisons to a global literature on school choice and parent involvement. In the findings section, we explain how the complicated primary school preference system creates structure-reinforced privilege by allowing parents with economic, social and cultural capital advantages to boost their children's chance of admissions into "perceived" elite 
schools. This competitive process and the discourse surrounding it hardens school reputations contributing socioeconomic segregation and ultimately, greater social inequality.

\section{Findings}

\section{Navigating the Complexity of the Primary School Lottery Selection Process}

Singapore's primary school registration system for the roughly 40,000 entering 7-yearolds creates structure-reinforced privilege through the way that it combines a large number of choices with an intricately tiered system of admissions preferences. Adding to the complexity, the continuous rebuilding of Singapore's schools and government subsidized apartments leads to fluctuations in the school catchment demographics, impacting the chance of admission. ${ }^{7}$ Given this complexity, instead of describing the system in its entirety, we focus on the public discourse of parents navigating several preference criteria in order to demonstrate how the complex structure, combining many choices, a multi-tiered preference system and opaque selection criteria lead to some families being privileged in the process.

One structural challenge confronting parents is the sheer number of choices which increases parental confusion and dissatisfaction (Iyengar and Lepper 2000). For Singaporean children entering the first year of primary school, the 185 government-funded and governmentaided primary schools are theoretically available in their set of choices, depending on the gender of the child. At the time of primary school registration, families choose a school from a series of parameters including home-school distance, available second language options ${ }^{8}$ and extracurricular activities.

\footnotetext{
${ }^{7}$ A parent website shares updates to help parents track school construction projects, https://elite.com.sg/schoolchange

${ }^{8}$ Most primary schools offer Chinese, Malay and Tamil as a second language.
} 
A second structural design that reinforces parental privilege is the complicated six-part preference system called phases, shown in Table 2, that is layered on to the large choice set. Within each of the six phases, further preference is given to children based on two additional criteria a) their citizenship status (since 2012, Singaporeans have absolute priority over permanent residents), and b) home-school distance. At any one phase, families select one primary school, and if they fail to secure a spot in that school, they will register again in the next phase for which they are eligible. During each phase, if there are more applications than spots, the selection shifts to a ballot, a random lottery to select the students but with priority given to Singaporeans and those who live nearest to the school of choice.

Table 2: Primary One Registration Phases

\begin{tabular}{ll|l}
\multicolumn{1}{c}{ Phases } & Eligibility & Competitiveness \\
\hline & Child with a sibling currently enrolled. & Guaranteed admission.
\end{tabular}

2A(1) Child whose parent is either a registered alumni of the primary school alumni association, or a member of the school advisory committee.

Tier 1 schools may be oversubscribed at this phase.

2A(2) Child whose parent or sibling studied in the Tier 1 schools may be school, or whose parent is a staff member. oversubscribed at this phase. Children enrolled in the school's MOE kindergarten.

2B Child whose parent served as a school volunteer, community volunteer or affiliated church or clan member.

20 places reserved. Tier 1 and 2 schools may be oversubscribed at this phase.

2C All children who have not secured a place in an earlier phase.

20 places reserved. Most Tier 1 (and some Tier 2) schools will be oversubscribed. 
2C All children who have not secured a place (Supple- in an earlier phase and non-citizens and mentary) permanent residents.
All Tier 1 and 2 schools will be oversubscribed at this phase.

Given that many schools were founded by religious orders or ethnic groups and later incorporated into the Singaporean state system, some of the preferences reflect these historical ties, or as explained by then Education Minister Ong Ye Kung in a speech in 2019, they "[uphold] the tradition and culture of the schools and the community that started them" (The Newpaper, 2019). While the preferences are designed to favor families with pre-existing school affiliations, many of the phases offer a clear benefit to those with economic, cultural and social capital, as will be explained in the next section. Furthermore, parents with multiple ties (for example being an alumni, having a religious association) have extra tries at admission via several phases before Phase $2 \mathrm{C}$ where the process opens to everyone with the exception of foreigners who are not permanent residents. ${ }^{9}$ Given that legacy benefit (Phase 2A) and parent volunteer (Phase 2B) emerged from our data as the two most discussed priorities, our analysis that follows will focus on the public discourse around these two registration phases, and how the registration structure reinforces existing parental privilege.

\section{Legacy benefit}

One way that the Singaporean preference structure reinforces privilege is through benefitting parents who have legacy status as old boys and girls at their elementary schools. Parents who are registered members of the primary school alumni associations can register their child for that school in Phase 2A(1) of the exercise, and in phase 2A(2) if places are still

\footnotetext{
${ }^{9}$ Registration for non-permanent resident foreigners occurs at the end of the Primary 1 registration after Singaporean citizens and permanent residents have been enrolled. These children are assigned to an available school closest to their homes.
} 
available for non-association alumni members. Although this benefit is available to any alumnus of any primary school, in practice, alumni status is more rewarding for those who have attended elite primary schools because access can be "pass[ed] down like a family heirloom" (sleepy, July 28, 2010). Moreover, qualifying for $2 \mathrm{~A}(1)$ status at some schools requires additional capital. Becoming a recognized alumni is not automatic, typically involving a one-time joining fee of as much as S\$1,000 (about US\$700), an amount that one parent deemed "exorbitant" (Chia and Davie 2013). According to the Nanyang School Alumni Association website, as of 2020, aspiring Nanyang Primary School alumni also need to volunteer in at least two approved alumni or school events in addition to paying fees, followed by a review by the committee to decide if their membership application is approved. Such a costly and tedious process may be worthwhile to some families, since all children registered at this phase will get a place, barring special circumstances such as the Year of Dragon baby boom that resulted in two Tier 1 schools being oversubscribed at Phase 2A(1) in the 2018 registration. However, this preference also advantages parents who are alumni and are able to pay.

Meanwhile, a number of parents who attended less elite schools sometimes found that their primary schools no longer exist when they started considering options for their children, demolished as part of Singapore's rebuilding efforts. User toddles was one of several to note "I topped my neighbourhood school but then it closed down/merged. boo hoo." (July 28, 2010). Theoretically, alumni status would then be assigned to another school, but the process was unclear, and the alumni connection became even more tenuous to their reassigned preference.

Parents' dissatisfaction with alumni preference was emphasized through parents' discourse both in the news and on Kiasuparents. Parents like Red-Rhino joked that they should ask prospective partners "which former primary school do you come from?” (July 23, 2008). As 
mummy168 commented ruefully, "Generations of the 'privileged' group will continue to be guaranteed places in their school of choice just by the very virtue that their parents have studied in the particular school; creating a snowball effect...the 'in' group vs 'out' group. Yet we pledge democracy and equality as citizens of Singapore?" (January 20, 2011). As Kiasuparents users argued, the legacy preference allows parents with alumni status, especially at an elite school, to pass along their privilege to the next generation, thus exemplifying a structure-reinforced privilege.

\section{Parent volunteers}

Just as alumni preference was intended to build strong family ties with a school over generations, volunteer preference, which started in 1998, was designed to encourage parents to get to know a school well before enrolling their child. In ensuing years, however, successfully volunteering at the most elite schools has evolved into a selection mechanism for parents with the time and cultural capital, resulting in a structure-reinforced privilege.

According to parents' discussions in Kiasuparents, volunteers complete a minimum of 40 hours of service performing tasks that range from recess duty, traffic warden and field trip chaperone to more specialized assignments like leading career talks, photographing school events and coaching sports. To qualify as a volunteer, parents complete an application and are interviewed by the school administration. For example, a parent volunteer application form on the Nanyang Primary School's website shows that schools may ask parents to list their educational and professional background and include a curriculum vitae. The process is not transparent: many parents post queries on the Kiasuparents forum in confusion about how early 
to start the application process. Adding to the complexity, the deadlines and expectations differ at every school.

As expected, Tier 1 and 2 schools tend to attract many more parent volunteers each year compared to Tier 3 neighborhood schools. As a result, some schools raise the bar by stipulating longer hours of service, up to 80 hours in the case of Nanyang Primary School (Tier 1) and Chongfu School (Tier 2) (Coke Chan July 27 2017, J. Ng, 2012). In addition, some schools ask parents to develop proposals to justify how their contribution provides a "value add" (floppy August 28 2017). Even with these stringent requirements, Tier 1 and 2 schools typically receive 100 to 200 applications each year, but accept no more than 30 volunteers (J. Ng 2012).

The parent volunteer scheme is also complex for school administrators who must coordinate and log volunteer hours. Parents complain on Kiasuparents when the schools are not forthcoming enough with volunteer opportunities for them. "The first challenge is getting into the scheme. The next challenge is clocking the required hours. Some schools are proactive in allocating duties; others are reactive.” (floppy July 1 2019). Some schools with active current parents have even stopped taking prospective parent volunteers entirely (Lee 2014).

Kiasuparents report desperate measures, in some cases applying to be parent volunteers at multiple schools. This in turn creates a sense of disempowerment, as user Zac's mum explains, "the school will choose u, not u choose the school [sic]" (January 8 2018). While the parent volunteer scheme creates a closer parent-school bond for a select group of parents, it reinforces new parents' first experience of the Singaporean school system as one that is selective and hierarchical even before their children enter school. The complexity of the parent volunteer signup procedure, coupled with the vague selection criteria and the many hours of services required mean that only parents who are resourceful enough to seek out information, as well as those who 
have the skills and time to contribute as a volunteer will benefit disproportionately from this system.

\section{How the choice complexity impacts Singaporean parents}

Instead of the common refrain that kiasu parents are to blame for the system being too competitive, the discourse analysis revealed that parents react to the complex choice structure, repeatedly describing themselves at the mercy of an unfair system, feeling "lost" "heavy at heart," and "losing sleep" over the process. This shows that the phenomenon of structurereinforced privilege is one that is widely acknowledged and recognized even among the parents, and may even be perpetuated by such discourse through justification and normalization. As user janet 88 wrote, "Parents are kiasu, but that's because we are made to be such" (July 22 2010). In the final section of the paper, we consider how the primary registration system impacts parents' choices, their sense of fairness of the process and how they might change the system.

Rather than blaming each other for being too kiasu, Kiasuparents users work collaboratively to navigate the enrollment system and joke about their own kiasu-ness, "never thot $\mathrm{i}$ wil become a kiasu parent but it seems the day is finally here [sic].” Older parents who have gone through the system are called site "Gurus" and stay on to respond to new parent queries. For some parents, the schools' academic track records are important, and now that MOE and the media no longer publish this information, users of Kiasuparents compile data on the top PSLE performers at each elementary school into widely shared tables. But discussion on Kiasuparents about what made a school "good" ranged widely, with many users echoing MOE recommendations advising new parents to broaden their scope beyond test results. Discussed factors included the amount of homework, teacher and principal quality, a single-sex versus a coeducational school, the peer group and parent community, the stress of a long commute, and 
available extracurricular activities. Some parents even advocated for parents to exit the "rat race" amidst concerns about children's stress and too much homework. One mother explained the mental health benefits of sending her children to a "less competitive environment...My husband and I just want our children to be happy and not be overly stressed" (The Straits Times 2015).

A sample query to Kiasuparents helps give a sense of how conversant parents needed to be in a series of complex calculations about exercising various preferences, and how confused they still feel in weighing their options. A parent a year away from primary 1 registration asked:

My preference is [Catholic High School] and will be moving to Bishan to fall within $1 \mathrm{~km}$, but I'm not sure if it is still risky. A backup plan is to use grandparents' address for [St. Joseph's Institution Junior] (their address is $1-2 \mathrm{~km}$ ). ${ }^{10}$ We are Catholics so I presume we will fall in phase 2B for both schools. May I know:

1. based on past stats, is SJIJ $1-2 \mathrm{~km}$ safer than CHS $<1 \mathrm{~km}$ ?

2. do we still qualify for phase $2 \mathrm{~B}$ if using grandparents' address?

3. If I were to apply to CHS and if it seems like it is oversubscribed, can I still change to SJIJ by applying using a different address for phase 2B? (stay0, October 5, 2017)

Stay0's query demonstrates a parent already conversant in how the system works, trying to calculate their odds of admission at a variety of schools, rather than selecting a clear preference. The terms "risk" and "safer" demonstrate that even the parents who are able to exercise phase preferences feel that there are no guaranteed options. Repeatedly, advice on Kiasuparents and in the newspapers centered around figuring out the balloting odds to select a school you can get into. A mother explained her strategy to The New Paper, "Rather than ballot or wait, I would rather be sure that there's a place for [my daughter]" (Heng and Fu 2013). In the end, above

\footnotetext{
${ }^{10}$ Singaporeans can use a relative's address if they are a primary caregiver for a child of working parents.
} 
many options, parents want the security of a safe choice. Importantly, the discourse shows that the availability of unlimited choices, coupled with the complexity of the system make the registration process a difficult and possibly resource-intensive endeavour for parents hoping to enroll their children into selective (Tier 1 or 2) schools.

The stress of balloting comes to a head during the three days of Phase $2 \mathrm{C}$ registration, where the process opens up to everyone without prior preferences. Enrollment figures at each school are closely monitored and shared in real time on Kiasuparents, and it is common for many parents to update their preferences during these three days as they get the enrollment numbers from each school, weighing the odds between a more prestigious choice that might shift to a ballot if it is oversubscribed versus a tier 2 or tier 3 school that will have guaranteed spots. Often parents who secured an alumni spot at a non-elite school strategically follow Phase $2 \mathrm{C}$ numbers in case the odds look favorable to move their selection to a more prestigious school. The final half hour of Phase $2 \mathrm{C}$ registration often has parents waiting down the clock, one parent stationed at the alumni school, ready to give up their child's guaranteed spot, while the other parent submits a new application to the preferred (often Tier 1 or 2) school (Chen 2013). In fact, Phase $2 \mathrm{C}$ is so competitive that by the end of the three-day registration period, about half of the schools are oversubscribed, according to $2019 \mathrm{P} 1$ registration statistics analysis on Kiasuparents.

Thus, as a result of the enrollment process, the primary concern superseding all other considerations is finding the most elite school that is also a safe choice. Following a somewhat circular logic, popular demand reinforces the perception of an elite school, as long as it is not so elite to still have available places. For example, Alexandra Primary School opened in 2014 and was oversubscribed immediately despite not having any graduate test results, in part because its founding principals came from two very popular schools (Lee and Teng 2015). Thus once a 
school becomes popular through registration, information shared and amplified in forums like Kiasuparents solidifies its reputation. This popularity, amplified in data shared in online discussion forums, perpetuates the perception of a discrepancy in the quality of the schools. Thus the competition and uncertainty built into the choice process fuels parents' incentive to exercise their privilege to enroll their children in what they perceive to be "good" schools. Interestingly, this also works against the efforts of the government to reassure people that "every school is a good school" (P. T. Ng 2017).

Each year, the Primary one registration exercise remains one of the most reported and hotly debated topics in the local press between June and August. These public debates show the prominence accorded to this process, and the government's willingness to respond to public criticism. On both Kiasuparents and in newspaper articles, the most frequent target of criticism was the alumni preference, particularly after reports that in recent years, 28 of the most popular schools took in half or more of their enrollments in the alumni phase (Davie 2013). A number of parents argued that preferences that reward families for their inherited privileges are unfair in the context of public schools when alumnus can "turn up at the school gates 25 years later to claim a spot for his son" (Goh 2012). Other parents defended the legacy benefit and the volunteer system, echoing the government's stance that admissions priority to families with school ties is an important step towards recognizing and rewarding alumni's efforts in "strengthening the school's tradition and ethos" (Chia and Davie 2013).

The government also responded quickly to these public debates. To ensure that more places are available to families without alumni connections, Prime Minister Lee Hsien Loong announced in the 2013 National Day Rally that 40 places at each school would be set aside for Phases 2B and 2C (Lee and Tan 2013). In response to complaints that parents were abusing the 
distance priority system by renting flats that they never lived in near popular schools, in 2015 the government stipulated a 30-month residency requirement after registration (Toh 2012). These changes demonstrate the importance of public debate in Singapore about the primary one school registration process and the government's responsiveness to parents' concerns.

Yet, even with these responses, some parents and journalists suggest the changes do not go far enough in creating a fair system, and that the choice structure as it exists still disproportionately benefits families with existing privileges. A 2013 Straits Times editorial argued for removing preferences aside from sibling priority and requiring everyone to participate in a lottery, a process they deemed "eminently democratic...and more in keeping with the Singaporean notion of fair play" (The Straits Times 2013). Other commentators suggested increasing the number of spots for students with no prior school affiliation while reducing the spots to alumni (Davie 2013, 2014, Lee and Tan 2013). Finally, others noted that Tier 1 elite schools tend to be concentrated in wealthy neighborhoods, and recommended either relocating schools or forgoing the home-distance preference to the most elite schools (Davie 2014, The Straits Times 2013). In these recommendations, parents and journalists repeatedly called for a reform of the choice system to reduce the privileges it currently renders, therefore giving greater priority to unaffiliated families.

\section{Conclusion}

This article has argued for the importance of studying how parents make sense of school choice structures through examining the primary school choice enrollment process in Singapore. First, although the Singapore priority registration system was created to strengthen existing family and community connections with schools, it gives undue advantage to parents who 
already possess economic, cultural and social capital. Parents face a lottery system with too many choices, a complex set of preferences many of which, like the parent volunteer scheme, are not transparent. The most savvy parents who can access the online forum Kiasuparents are still confused and anxious, suggesting that non-users are at an even greater disadvantage. Unlike prior arguments that parental pressure drives the competitiveness of the Singaporean system, parents repeatedly describe themselves at the mercy of an unfair system, feeling stressed and anxious. Those who have attended elite schools and can afford to pay the S\$1000 registration fee can draw on their alumni status, those with an abundance of time and relevant skills can become parent volunteers, and those with money can purchase a house within a kilometer of their desired school. Working parents, particularly those who have not attended prestigious schools or without significant skills have none of these advantages, and end up taking their place at the end of the line.

Second, the confusing system creates a perception of unfairness. Rather than having an equal shot at academic success that underpins the philosophy of a meritocracy, children are sorted at the moment they begin school. Given the increasing concerns over socioeconomic stratification in Singapore and elite entrenchment in prestigious schools, such a perception ultimately undermines community cohesion. These arguments add to a broader theoretical contribution of structure-reinforced privilege, showing that parents' privileges are amplified by school choice structures. Failing to recognize this risks blaming parents for exercising privileges in structures that were set up to allow and encourage them to do so. Such analysis suggests the benefits of redesigning school choice structures away from an individual benefit to one framed around goals of collective equity (Orfield and Frankenberg 2013). 
Singaporean parents have many ideas for changes to the system, and MOE has been responsive, such as setting aside seats in later phases to ensure access or tightening regulations around residency. While we recognize that families will experience anxiety whenever there exists uncertainty in enrolling their children at school, additional changes could reduce the stress of the choice process, decrease the likelihood of parents exercising privilege in the system, and increase student socioeconomic diversity. Many of these recommendations have already been debated publicly in the press and in online groups (Davie 2013, The Straits Times 2013).

First, research shows that unlimited choice is counterproductive, and choice structures can better support parents with a more limited set of choices. Singapore's secondary school admission process allows for six choices. A similar move to reduce school choices in primary registration through allowing parents to create a ranked preference of a few schools (several in a close home-school distance, several across geographic boundaries) would reduce parental anxiety in navigating so many choices, and prevent a scenario where failing to ballot into the selected school results in enrolling in another that is much less preferred or far away from home. Second, the confusion of even well-informed parents suggests the need for choice systems to have a consistent and transparent selection process across schools. Third, removing the number of privileged groups by retaining sibling and distance preference but requiring everyone else to ballot could also make the system equitable for those without prior affiliations or the cultural capital and economic resources to volunteer their time (Davie 2013, The Straits Times 2013). Third, given that such a change could benefit those in wealthy neighborhoods where elite schools tend to be located, we recommend creating a set-aside provision for disadvantaged families. In Singapore, this could involve reserving Primary 1 spots for low-income families especially at Tier 1 and Tier 2 schools to increase diversity in these schools. This low-income preference is 
consistent with the 44 MOE-run kindergartens that reserve one third of spots for children from low-income families and is also being implemented successfully in a number of American school districts (Ang 2019, Potter, Quick and Davies 2016). Finally, in school choice systems, the equitable geographic distribution of schools matters. In Singapore, as new schools are constructed, the government can make a policy to redistribute the most elite schools throughout the island, such as the recent move of Raffles Girls' School, a Tier 1 school, away from a wealthy neighborhood (Davie 2014).

We acknowledge that these recommendations to provide greater access are only the first step in supporting low-income students at elite schools, and supports for students after enrollment are outside of the scope of this paper. Moreover, our Kiasuparents sample presents limited insights about the experience of low-income, non-English speaking parents. Additional research like that of Chiong and Dimmock (2020) is needed to represent low-income and minority Singaporeans navigating the school registration process.

While we argue in this paper that choice structures matter and that they can be changed to be more equitable, parents can still play an important role. As early as 2010, ChiefKiasu, one of the founders of Kiasuparents, was advocating for parents to "think outside the box" by sending their children to the more "ordinary school." By being "pioneers," children could excel and in doing so, "bring pride and glory to the school...Just imagine - It is our children that made the schools, and not the other way around" (July 28 2010). Influential parents, like the parent "Gurus" on Kiasuparents, can play a positive role in encouraging parents to consider a wider set of school choices. Research has shown that parents who find a peer group of like-minded parents will be willing to make a school choice that might otherwise have seemed risky on their own (Posey-Maddox 2014). 
Designing an equitable choice process requires a precise balancing act between what is practical, what those with power demand and what is most equitable. As societies face increased social inequality from the current covid-19 crisis, prioritizing around equity becomes even more important. The Singapore case study suggests that globally, school choice systems can be better designed when they provide a small set of quality choices to parents, when processes are transparent and consistently applied, and when preferences grant priority access to the neediest families rather than those who already have privileges. Simplified lottery processes (where all schools and families are combined in one single enrollment system), weighted enrollments and set-asides for low income families in some US cities suggest avenues to support the least advantaged families and make choice systems fairer for everyone (Potter, Quick and Davies 2016).

Singapore has delivered impressive academic results in a comprehensive public education system, but policy makers continue to strive for a more inclusive, equitable and student-centered education system (P. T. Ng 2017). Instead of blaming the parents for being too kiasu, making the primary enrollment process simpler and fairer is an important step towards that broader goal. 
Mira Debs is the Executive Director of Yale's Education Studies Program and a lecturer in the Department of Sociology. In 2020, she was a Visiting Professor at Yale-NUS College in Singapore. Her research focuses on how parents choose schools in a variety of schooling contexts including the US and Singapore, and the impact of individual choices on school segregation.

Hoi Shan Cheung is an Assistant Professor of Psychology at Yale-NUS College. Her research focuses on social stratification in Singapore schools in relation to children's academic selfconcept and aspirations, as well as the effects of parental expectations on academic stress.

\section{ORCID}

Mira Debs https://orcid.org/0000-0001-5234-0689

Twitter:@mira_debs

Facebook https://www.facebook.com/mira.debs

Linkedin: https://www.linkedin.com/in/miradebs/

Hoi Shan Cheung https://orcid.org/0000-0002-2551-170X

Acknowledgements The authors thank Laik Won Teh, Madeline Pérez, Meredith McNocchie, Stephanie Wong, Elise Castillo, Xiaoling Lin, Rayner Ng, Natalie Sutanto and students of the Yale-NUS Comparative International Education seminar for their insights and editorial suggestions; and Chris Tang for rendering library search support.

Disclosure statement No potential conflict of interest was reported by the author(s). 


\section{References}

Adamson, Frank, Bjorn Åstrand, and Linda Darling-Hammond. 2016. Global Education Reform: How Privatization and Public Investment Influence Education Outcomes. New York: Routledge.

Ang, Jolene. 2018. "Independent schools to be made more affordable for less well-off.” The Straits Times. December 27. https://www.straitstimes.com/singapore/education/independent-schools-to-be-mademore-affordable-for-less-well-off

Ang, Jolene. 2019. "Parents can register online for MOE kindergartens, which will give greater priority to low-income kids." The Straits Times, January 15. https://www.straitstimes.com/singapore/education/parents-can-now-register-online-formoe-kindergartens-which-will-give-greater

Ball, Stephen J., and Carol Vincent. 1998. "'I Heard it on the Grapevine':'Hot' Knowledge and School Choice." British Journal of Sociology of Education 19(3): 377-400.

Barr, Michael D., and Zlatko Skrbiš. 2008. Constructing Singapore: Elitism, Ethnicity and the Nation-Building Project. Copenhagen: Nias Press.

Bourdieu, Pierre. 1996. The State Nobility: Elite Schools in the Field of Power. Palo Alto: Stanford University Press.

Bourdieu, Pierre. 1986. "The Forms of Capital.” in Mark Granovetter and Richard Swedberg, ed. The Sociology of Economic Life. Routledge.

Breidenstein, Georg, Jens Oliver Krüger, and Anna Roch. 2020. "Parents as 'customers'? The perspective of the "providers' of school education. A case study from Germany." Comparative Education, 56(3): 409-422. doi: 10.1080/03050068.2020.1724485

Byun, Soo-yong, Kyung-keun Kim, and Hyunjoon Park. 2012. "School Choice and Educational Inequality in South Korea." Journal of School Choice, 6(2): 158-183.

doi:10.1080/15582159.2012.673854

Chen, Andy. 2013. "Seriously Kidding: Comedy of Manners at P1 Registration." The Straits Times, August 25. Factiva.

Chew, Matthias. 2012. "MOE stops naming top students.” The Straits Times, November 21. Factiva.

Chia, Stacey and Sandra Davie. 2013. "20\% of P1 places go to those with ties to school." The Straits Times. June 25. https://www.straitstimes.com/singapore/20-of-p1-places-go-tothose-with-ties-to-school-0 
Chin, Hoong Chor, and Kok Wai Foong. 2006. "Influence of school accessibility on housing values." Journal of Urban Planning and Development, 132(3): 120-129.

Chiong, Charleen and Clive Dimmock. 2020. "Building Trust: How Low-Income Parents Navigate Neoliberalism in Singapore's Education System. Comparative Education, 56(3): 394-408. doi:10.1080/03050068.2020.1724487

Christensen, Søren. 2015. "Healthy Competition and Unsound Comparison: Reforming Educational Competition in Singapore." Globalisation, Societies and Education, 13(4): 553-573.

Chubb, John E., and Terry M. Moe. 1991. Politics, Markets and America's Schools. Washington, D.C.: Brookings Institution.

Darling-Hammond, Linda. 2015. The Flat World and Education: How America's Commitment to Equity will Determine our Future. New York: Teachers College Press.

Davie, Sandra. 2013. "Time to Change the P1 Priority System?” The Straits Times, July 11. https://www.straitstimes.com/opinion/time-to-change-p1-priority-system

Davie, Sandra. 2014. "Move Top Schools Out of Bukit Timah.” The Straits Times, August 7. https://www.straitstimes.com/opinion/move-top-schools-out-of-bukit-timah

Deng, Zongyi, and Saravanan Gopinathan. 2016. "PISA and High-Performing Education Systems: Explaining Singapore's Education Success." Comparative Education 52(4): 449-472. doi: 10.1080/03050068.2016.1219535

Dronkers, Jaap, and Péter Robert. 2008 "Differences in scholastic achievement of public, private government-dependent, and private independent schools: A cross-national analysis." Educational Policy 22, no. 4 : 541-577.

Dumont, Hanna, Denise Klinge, and Kai Maaz. 2019. "The Many (Subtle) Ways Parents Game the System: Mixed-Method Evidence on the Transition into Secondary-School Tracks in Germany." Sociology of Education, 92(2) : 199-228. doi:

$10.1177 \% 2 \mathrm{~F} 0038040719838223$

Forsey, M., Davies, S., \& Walford, G. (Eds.). (2008, May). The globalisation of school choice? Oxford, UK: Symposium Books Ltd.

Freidus, Alexandra. 2019. "A Great School Benefits Us All: Advantaged Parents and the Gentrification of an Urban Public School." Urban Education 54(8): 1121-1148. doi: $10.1177 \% 2 \mathrm{~F} 0042085916636656$

George, Cherian. 2012. Freedom from the Press: Journalism and State Power in Singapore. NUS Press.

Goh, Chor Boon, and Saravanan Gopinathan. 2008. "The Development of Education in Singapore since 1965." In Toward a better future: Education and training for economic 
development in Singapore since 1965, edited by Sing Kong Lee, Chor Boon Goh, Birger Fredricksen and Jee Peng Tan. Washington DC: The World Bank.

Goh, Ricky K. K. 2012. "Focus on the Child”. Today, August 2. Factiva.

Heng, Janice, and Andrea Ong. 2013. "If Only Singaporeans Stopped to Think.” The Straits Times, August 23. Factiva.

Heng, Linette. 2013. "Website a Hit with Kiasu Parents.” The New Paper, July 28. https://www.asiaone.com/node/30447\#gsc.tab=0

Heng, Linette, and Jie Ying Fu. 2013. "Some Prefer Less Popular Schools.” The New Paper, August 20. Factiva.

Holtz, Peter, Nicole Kronberger, and Wolfgang Wagner. "Analyzing internet forums." Journal of Media Psychology (2012).

Iyengar, Sheena S., and Mark R. Lepper. 2000. "When Choice is Demotivating: Can One Desire Too Much of a Good Thing?" Journal of Personality and Social Psychology, 79(6): 9951006.

Johnstone, Barbara. 2018. Discourse Analysis. London: Wiley Blackwell.

Lee, Pearl, and Audrey Tan. 2013. "Reserving 40 Places in P1 Exercise 'a Right Step'.." The Straits Times, August 20. https://www.asiaone.com/reserving-40-places-p1-exerciseright-step?page $=1$

Lee, Pearl, and Amelia Teng. 2015. "Something New, Something Bold: New Primary Schools' Non-Academic Traits Appeal to Parents." The Straits Times, July 27. https://www.straitstimes.com/singapore/education/something-new-something-bold

Lee, Pearl. 2014. "Primary 1 Registration: 5 Things to Know About the Popular Parent Volunteer Scheme." The Straits Times, June 10. https://www.straitstimes.com/singapore/education/primary-1-registration-5-things-toknow-about-the-popular-parent-volunteer

Lubienski, Christopher, and Ee-Seul Yoon. 2017. "Introduction to the Special Issue: Studying School Choice in Canada." Education Policy Analysis Archives, 25(37): 1-10.

Makris, M. V. 2018. The chimera of choice: Gentrification, school choice, and community. Peabody Journal of Education, 93(4), 411-429.

Merry, Michael S., and Willem Boterman. 2020. "Educational inequality and state-sponsored elite education: the case of the Dutch gymnasium." Comparative Education, 56(4): 522546. doi: $10.1080 / 03050068.2020 .1771872$

Ng, Jane. 2012. "Want P1 Place? Suggest a Project." The Straits Times, May 20. Factiva 
Ng, Pak Tee. 2017. Learning from Singapore: The Power of Paradoxes. New York: Routledge.

OECD. 2018. Equity in Education: Breaking Down Barriers to Social Mobility. https://www.oecd.org/publications/equity-in-education-9789264073234-en.htm

Ong, Xiang Ling, and Hoi Shan Cheung. 2016. Schools and the Class Divide: An Examination of Children's Self-Concept and Aspirations in Singapore. Singapore Children's Society.

Orfield, Gary, and Erica Frankenberg. 2013. Educational Delusions? Why Choice can Deepen Inequality and How to Make Schools Fair. Berkeley, CA: University of California Press.

Park, Hyunjoon, Claudia Buchmann, Jaesung Choi, and Joseph J. Merry. 2016. "Learning Beyond the School Walls: Trends and Implications." Annual Review of Sociology 42: 231-252. doi: 10.1146/annurev-soc-081715-074341

Posey-Maddox, Linn. 2014. When Middle-Class Parents Choose Urban Schools: Class, Race, and the Challenge of Equity in Public Education. Chicago: University of Chicago Press.

Potter, Halley, Kimberly Quick, and Elizabeth Davies. 2016. A New Wave of School Integration. The Century Foundation (New York). http://apps.tcf.org/a-new-wave-of-schoolintegration.

Proctor, Helen, Anna Roch, Georg Breidenstein, and Martin Forsey. 2020. "Parents, Schools and the Twenty-first-century State: Comparative Perspectives." Comparative Education, 56(3): 317-330. doi: 10.1080/03050068.2020.1781422

Rosenbloom, Susan R. 2010. "My So-Called Choice: The Trappings of School Choice for NonAdmits." The Urban Review 42(1): 1-21.

Rowe, Emma, and Christopher Lubienski. 2017. "Shopping for Schools or Shopping for Peers: Public Schools and Catchment Area Segregation." Journal of Education Policy 32(3): 340-356. doi: 10.1080/02680939.2016.1263363

Saha, Lawrence J. 2003. "Cultural and social capital in Asian and Pacific countries." In International Handbook of Educational Research in the Asia-Pacific Region, pp. 59-72. Springer, Dordrecht.

Salman, Ali. 2010. "Liberate to learn: education vouchers in Pakistan." Economic Affairs, 30(3), :35-41.

Saraisky, Nancy G. 2015. “Analyzing Public Discourse: Using Media Content Analysis to Understand the Policy Process." Current Issues in Comparative Education 18(1): 26-41.

Shuffelton, Amy. "What parents know: risk and responsibility in United States education policy and parents' responses." Comparative Education (2020): 1-14.

Singapore Department of Statistics. 2019. "Population Trends, 2019."

https://www.singstat.gov.sg/-/media/files/publications/population/population2019.pdf 
Tan, Charlene. 2017 "Private Supplementary Tutoring and Parentocracy in Singapore." Interchange 48(4): 315-329.

Teng, Amelia, and Calvin Yang. 2016. "Going Beyond Grades: Evolving the Singapore Education System." The Straits Times, April 17. https://www.straitstimes.com/singapore/education/going-beyond-grades-evolving-thesingapore-education-system

Teo, You Yenn. 2019. This is What Inequality Looks Like. Singapore: Ethos Books.

Tham, Yuen-C. 2018. "Society Must Keep Social Networks Open: PM.” The Straits Times, May 17. https://www.straitstimes.com/politics/society-must-keep-social-networks-open-pm

The New Paper. 2019. "Singapore should not forget roots of Govt-aided schools: Ong," September 6. https://www.tnp.sg/news/singapore/singapore-should-not-forget-roots-govtaided-schools-ong

The Straits Times. 2008. No Priority P1 Registration, September 16. https:/www.asiaone.com/News/Education/Story/A1Story20080916-88179.html

The Straits Times. 2013. "Reform P1 System to Enhance Social Mobility." July 30. https://www.asiaone.com/reform-p1-system-enhance-social-mobility

The Straits Times. 2015. "Hot Picks and Top Picks: Why Some Parents Prefer Neighbourhood Schools.” July 13. https://www.straitstimes.com/singapore/hot-picks-and-top-picks-whysome-parents-prefer-neighbourhood-schools

Toh, Keziah. 2012. "Parents 'Renting' Their Way to Popular Schools?" The Straits Times, August 7. Factiva.

Waldow, Florian, Keita Takayama, and Youl-Kwan Sung. 2014. "Rethinking the pattern of external policy referencing: Media discourses over the 'Asian Tiger' PISA success in Australia, Germany and South Korea." Comparative Education 50(3): 302-321.Wu, Xiaoxin. 2012. "School choice with Chinese characteristics." Comparative Education 48 (3): $347-366$.

Wu, Xiaoxin. 2012. "School choice with Chinese characteristics." Comparative Education 48 (3): 347-366.

Yamamoto, Yoko, and Mary C. Brinton. "Cultural capital in East Asian educational systems: The case of Japan." Sociology of Education 83, no. 1 (2010): 67-83.

Zhou, Yisu, Yi-Lee Wong, and Wei Li. "Educational choice and marketization in Hong Kong: the case of direct subsidy scheme schools." Asia Pacific Education Review 16, no. 4 (2015): 627-636. 